\title{
Organic-N loss by efflux and burial associated with a low efflux of inorganic $N$ and with nitrate assimilation in Arctic sediments (Svalbard, Norway)
}

\author{
T. Henry Blackburn ${ }^{1, *}$, Per O. J. Hall ${ }^{2}$, Stefan Hulth ${ }^{2}$, Angela Landén ${ }^{2}$ \\ ${ }^{1}$ Department of Microbial Ecology, Institute of Biological Sciences, Aarhus University, DK-8000 Aarhus C, Denmark \\ ${ }^{2}$ Department of Analytical and Marine Chemistry, University of Göteborg, S-41296 Göteborg, Sweden
}

\begin{abstract}
Sediments were sampled at water depths from 170 to $2577 \mathrm{~m}$ at 17 stations adjacent to Svalbard. In general, with increasing water depth there was decreasing $\mathrm{NH}_{4}{ }^{+}$with increasing $\mathrm{NO}_{3}^{-}$in the sediment pore water, increasing depth of $\mathrm{O}_{2}$ penetration, decreasing $\mathrm{NH}_{4}{ }^{+}$- and increasing $\mathrm{NO}_{3}{ }^{-}$efflux rates, decreasing nitrification and denitrification rates, and decreasing rates of organic nitrogen burial. Most sediments had insignificant rates of nitrogen mineralisation $\left(0\right.$ to $\left.0.34 \mathrm{mmol} \mathrm{m} \mathrm{m}^{-2} \mathrm{~d}^{-1}\right)$; there was a very high $\mathrm{C}: \mathrm{N}$ ratio (mean 68 ) in the measured efflux products. Efflux and consumption rates of $\mathrm{NO}_{3}{ }^{-}$, calculated from pore water profiles, were generally higher than the measured rates, but these calculated rates also predicted high $\mathrm{C}: \mathrm{N}$ mineralisation ratios. The high ratios demanded that the particulate organic substrate must also have had a low mitrogen content. The high measured efflux of dissolved organic nitrogen (mean $0.93 \mathrm{mmol} \mathrm{m}^{-2} \mathrm{~d}^{-1}$ ) from the sediment suggested that fresh detritus (C:N 13) might reach the sediment surface, and be hydrolysed with efflux loss of dissolved nitrogenrich organic matter (e.g. C:N 6) and with subsequent mineralisation $(C: V \sim 68)$ or burial $\{C: N-10)$ of the transformed material. High $\mathrm{C}: \mathrm{N}$ ratios in the products of sediment mineralisation are commonly reported, indicating the prevalence of preferential nitrogen loss from detritus in the water column and probably also at the sediment-water interface. The retention of nitrogen by the sediment can explain the discrepancy between measured and calculated $\mathrm{NO}_{3}$ fluxes: $\mathrm{NO}_{3}{ }^{-}$did not escape from the sediment to the water because it was assimilated by bacteria utilising high C:N substrate. It is likely that some $\mathrm{NO}_{3}{ }^{-}$which diffused downward was also assimilated rather than denitrified. Many of these sediments had a sub-surface zone of $\mathrm{NH}_{4}{ }^{+}$production associated with nitrification. Above and below this zone of net production were zones of $\mathrm{NH}_{4}{ }^{+}$and $\mathrm{NO}_{3}$ disappearance.
\end{abstract}

KEYWORDS: Nitrate Ammonium DON Assimilation C:N - Nitrification - Denitrifıcation - Burial

\section{INTRODUCTION}

It has often been emphasised that much mineralisation of algal cells occurs in inshore sediments with the recycling of mineral nitrogen to the primary producers (Blackburn \& Henriksen 1983, Kemp et al. 1990). In sediments underlying deeper water, much less of the primary productivity reaches the sediment (Suess 1980) and the recycling of nitrogen is of less immediate importance, as the products take time to reach the photic zone. It is, however, of interest to determine the fate of the particulate organic nitrogen which reaches

•E-mail: henry@pop.bio.aau.dk the surface of deep sea sediments: burial, mineralisation or loss as dissolved organic nitrogen (DON). There are few reports on nitrogen cycling in Arctic sediments and those mostly relate to the shallow north Bering Sea and Chukchi Sea. In these regions there is preferential nitrogen mineralisation in the summer season (Blackburn 1987), there is a massive sedimentation of organic matter (Walsh et al. 1989), urea is a major component in sediment nitrogen cycling (Lomstein et al. 1989) and nitrification is linked to macrofaunal activity (Henriksen et al. 1993). It is seldom that all parameters are measured in the same system, but it was our aim to obtain as much data as possible: fluxes of $\mathrm{NH}_{4}{ }^{+}, \mathrm{NO}_{3}{ }^{-}$, urea and $D O N$; rates of nitrification and denitrification; 
high resolution pore water profiles of $\mathrm{O}_{2}, \mathrm{NH}_{4}^{+}$and $\mathrm{NO}_{3}^{-}$; rate of burial of particulate organic nitrogen $(P O N)_{i}$ and comparison of the nitrogen cycle with the behaviour of carbon. We describe how these data are combined to construct benthic nitrogen mass balances in order to assess the importance of nitrogen cycling in 17 sediments surrounding Svalbard, Norway.

\section{METHODS}

Stations were sampled during a cruise with the RV 'Polarstern' in June and July 1991; their locations are shown in Fig. 1, and the exact positions, dates and method of sediment sampling have been described (Hulth et al. 1994, 1996). Cores were obtained by either a multiple- or a box-corer. Water depth varied from 170 to $2577 \mathrm{~m}$, bottom water temperature was between +3 and $-2^{\circ} \mathrm{C}$, and salinity was between 34 and $36 \%$. The accumulation rate of PON in the sediments was measured by ${ }^{210} \mathrm{~Pb}$ analysis, as described for particulate organic carbon burial (P. Hall, S. Hulth \& T. Blackburn unpubl.). The efflux of $\mathrm{SCO}_{2}$ is reported elsewhere (Hall et al. unpubl.). Oxygen profiles were measured with an oxygen microsensor, as previously reported (Hulth et al. 1994).

The flux incubation procedure has been described in detail (Hulth et al. 1994, Hall et al. 1996, unpubl.). Briefly, the 35 to $50 \mathrm{~cm}$ long, $10 \mathrm{~cm}$ diameter Plexiglas core tubes $(0.4 \mathrm{~cm}$ wall) had a lid fitted with a stirring motor driving a Teflon bar; there were 2 Teflon valves. Cores were incubated with ambient overlying bottom

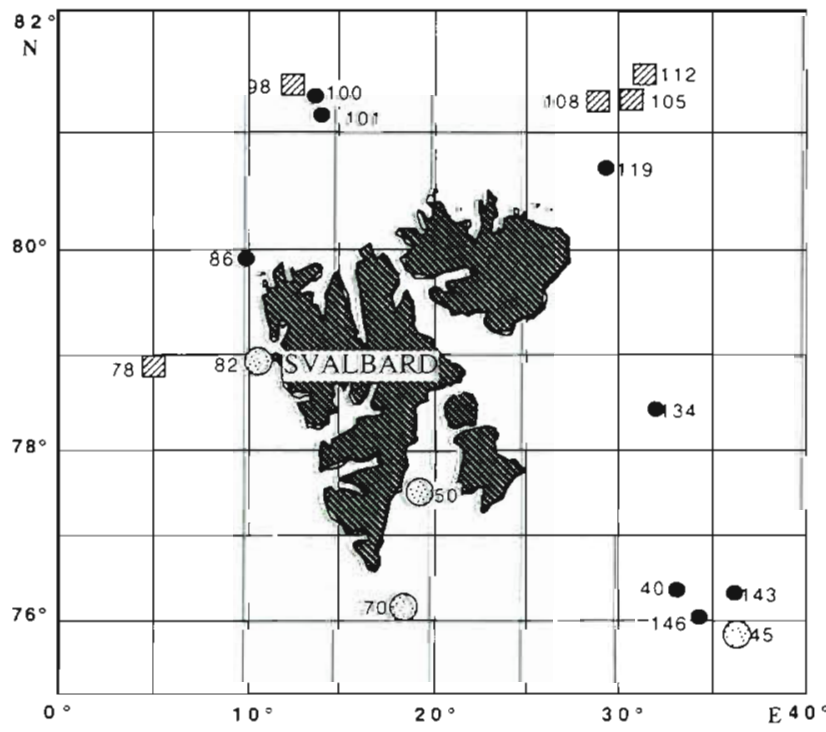

Fig. 1. Sediment sampling stations around Svalbard, Norway. (ש) Stations in Group 1; (O) Group 2; (C) Group 3 water, without a head space, in the dark at in situ temperature. Samples were removed through one Teflon valve, being replaced by bottom water through the other valve, without mixing. The interval between samplings was such that $\mathrm{O}_{2}$ was not depleted by more than $20 \%$. Nutrient concentrations were measured in the water samples: ammonium (Bower \& Holm-Hansen 1980), nitrate+nitrite (Wood et al. 1967), and urea (Price \& Harrison 1987); DON was determined by subtraction of dissolved inorganic nitrogen (DIN) from the total dissolved nitrogen, as measured by high temperature combustion in an Antek nitrogen analyser (Walsh 1989). The concentrations, corrected for water replacement, were plotted against incubation time to give flux rates. One or more cores, after initial incubation, were treated with $1 \%$ acetylene to inhibit nitrification (Sloth et al. 1992). The $\mathrm{NH}_{4}{ }^{+}$, which would have been oxidised to $\mathrm{NO}_{3}{ }^{-}$in the absence of acetylene, was measured as previously described and the increase in efflux rate taken as a measurement of nitrification.

To measure benthic denitrification we used a modif cation of the nitrogen isotope pairing technique (Nielsen 1992), in which 4 sediment cores of $-3.8 \mathrm{~cm}$ length were taken in short Plexiglas tubes $(7.5 \mathrm{~cm}$ long, $3.5 \mathrm{~cm}$ diam.). The overlying water was removed and replaced by bottom water to which had been added ${ }^{15} \mathrm{~N}-\mathrm{NO}_{3}^{-}(99 \%)$ to a concentration of $10 \mu \mathrm{M}$, thus approximately doubling the $\mathrm{NO}_{3}{ }^{-}$concentration. The tubes were stoppered; $3.0 \mathrm{ml}$ of $20 \% \mathrm{O}_{2}$ in helium was introduced as a bubble before incubation at in situ temperature in the dark. This prevented oxygen depletion. The overlying water was gently stirred by a suspended magnet. Sediments were incubated for varying times, depending on the depth of $\mathrm{O}_{2}$ penetration: Stns 40,45, $50,70,78,86$ and 143 for $1 \mathrm{~d}$; Stns 100 and 101 for $2 \mathrm{~d}$; Stns 105, 108, 112 and 119 for $3 d$. After incubation, the sediment in 2 tubes was resuspended in the overlying water and the gas bubble transferred to a pre-evacuated Vacutainer. The remaining 2 cores were re-incubated for the same length of time and were then mixed and sampled in the same way. The ${ }^{15} \mathrm{~N}^{15} \mathrm{~N}$ and ${ }^{15} \mathrm{~N}^{14} \mathrm{~N}$ were measured on an isotope ratio mass spectrometer (Nielsen 1992). The rate of denitrification was based on the difference between the gas samples extracted at the 2 different times. Denitrification of nitrate from the water (NO3w) was defined as Dw, and denitrification of nitrate which was produced in the sediment by nitrification (NO3n) was defined as Dn.

Pore water was obtained by sectioning $3.5 \mathrm{~cm}$ diameter sediment cores into $0.2 \mathrm{~cm}$ slices from the surface to at least $1.6 \mathrm{~cm}$ within $1 \mathrm{~h}$ of retrieval. Sectioning was performed at $0^{\circ} \mathrm{C}$. The sediment slices were centrifuged at $3000 \times g$ at in situ temperature. At some stations, pore water samples were obtained by sectioning $10 \mathrm{~cm}$ diameter cores into slices $0-1 \mathrm{~cm}, 1-2 \mathrm{~cm}$, 
$2-3 \mathrm{~cm}, 3-4 \mathrm{~cm}, 4-6 \mathrm{~cm}$ and $6-8 \mathrm{~cm}$. After centrifugation, the pore water was filtered through $0.45 \mu \mathrm{m}$ prewashed cellulose acetate filters. Ammonium, urea, and $\mathrm{NO}_{3}{ }^{-}+\mathrm{NO}_{2}{ }^{-}$were measured by the methods above. The net diffusive flux of $\mathrm{NO}_{3}^{-}$upward to the overlying water and downward to the lower sediment layers $\left(J_{\text {diff }}\right)$ was calculated as for $\mathrm{O}_{2}$ influx (Hulth et al. 1994), using Fick's first law adapted to sediments:

$$
J_{d, f}=-\phi \times D_{s} \times \mathrm{d} C / \mathrm{d} x(\text { Berner 1980) }
$$

where $\phi$ is the porosity, $\mathrm{d} C / \mathrm{d} x$ is the concentration gradient and $D_{s}$ is the free diffusion coefficient $(D)$ for $\mathrm{NO}_{3}{ }^{-}$, corrected for temperature (Li \& Gregory 1973) and porosity:

$$
D_{3}=D \times \phi \times \phi
$$

\section{RESULTS}

The stations were assigned to 1 of 3 groups, mostly on the basis of the $\mathrm{NH}_{4}{ }^{+}$and $\mathrm{NO}_{3}{ }^{-}$profiles and $\mathrm{O}_{2}$ penetration depth (Fig. 2), but also on the basis of the depth and position of the station (Fig. 1, Table 1). The reason for the emphasis on pore water profiles will become evident in the 'Discussion'. Group 1 was south and mostly to the west of Svalbard (Stn 45 lying to the east); all the stations in this group were relatively shallow. Group 2 had mixed depths (188 to $869 \mathrm{~m}$ ) and all stations were relatively close to the coast. Group 3 stations were generally deep (405 to $2577 \mathrm{~m}$ ) and to the north of Svalbard, except for Stn 78. The stations for which data were available were arranged in order of decreasing biological activity, as reflected in the general decrease in pore water $\mathrm{NH}_{4}{ }^{+}$and in the increasing depth of penetration of $\mathrm{NO}_{3}{ }^{-}$and $\mathrm{O}_{2}$ (Fig. 2). The measured sediment-water fluxes of $\mathrm{NH}_{4}{ }^{+}$, urea- $\mathrm{N}, \mathrm{NO}_{3}{ }^{-}$ and $\mathrm{N}_{2}-\mathrm{N}$ (denitrification $\mathrm{Dn}$ ) for the various stations summarise the main products of organic nitrogen mineralisation (Table 1). The biologically active stations (Group 1) had an efflux of $\mathrm{NH}_{4}{ }^{+}$(Stn 82 was not measured). The less active stations (Groups 2 and 3) had zero- or negative effluxes of $\mathrm{NH}_{4}{ }^{+}$, except for $\mathrm{Stn} 40$ in Group 2 and Stn 78 in Group 3. Urea flux could be positive or negative, was always small and was not correlated with sediment activity. The flux of nitrate was variable in Groups 1 and 2 (efflux in 6 out of 11 cases), but in Group 3 there was always an efflux. Denitrification of $\mathrm{NO}_{3}^{-}$produced within the sediment (Dn, see Table 3) decreased from low values in Group 1 to zero in Group 3. The sum of the positive net inorganic effluxes ( $\Sigma N$ inorg.) was very small in relation to the net efflux of DON.

The calculated $\mathrm{NO}_{3}{ }^{-}$fluxes are shown in Table 2 . The procedure for these calculations is described in the 'Methods'. Nitrate in the overlying water was defined as NO3w, and nitrate from sediment nitrification as NO3n. Although all diffusional fluxes were 'net' processes, the term net was restricted to fluxes which involved both NO3w and NO3n. Only Stns 45 and 70 showed a calculated net influx, whereas many stations

Table 1. Measured net efflux ( $\mathrm{mmol} \mathrm{m} \mathrm{m}^{-2} \mathrm{~d}^{-1} \pm \mathrm{SD}, \mathrm{n}=3$ ) of nitrogen species. The $\sum \mathrm{N}$ inorg. rate is the sum of the positive effluxes of ammonium, urea, nitrate and dinitrogen. Dinitrogen efflux was the measured rate of coupled nitrification-denitrification (Dn,

\begin{tabular}{|c|c|c|c|c|c|c|c|}
\hline Stn & Depth (m) & $\mathrm{NH}_{4}{ }^{+}$ & Urea-N & $\mathrm{NO}_{3}^{-}$ & $\mathrm{N}_{2}-\mathrm{N}$ & $\sum N$ inorg. & $\mathrm{DON}$ \\
\hline \multicolumn{8}{|c|}{ Group 1} \\
\hline $045^{\circ}$ & 240 & $0.18 \pm 0.07$ & $-0.05 \pm 0.02$ & $0.08 \pm 0.02$ & 0.08 & 0.34 & $1.20 \pm 0.18$ \\
\hline 070 & 318 & $0.14 \pm 0.05$ & $-0.03 \pm 0.07$ & $-0.15 \pm 0.09$ & 0.07 & 0.20 & $1.06 \pm 1.31$ \\
\hline 050 & 170 & $0.24 \pm 0.28$ & $0.11 \pm 0.02$ & $-0.17=0.14$ & 0.01 & 0.36 & $0.65 \pm 0.04$ \\
\hline 082 & 326 & nd & $-0.01 \pm 0.02$ & $0.15 \pm 0.02$ & 0.09 & 0.25 & $1.31 \pm 1.31$ \\
\hline \multicolumn{8}{|c|}{ Group 2} \\
\hline 040 & 191 & $0.02 \pm 0.34$ & $0.10 \pm 0.14$ & $-0.10 \pm 0.07$ & 0.05 & 0.18 & $0.65 \pm 0.70$ \\
\hline 143 & 188 & $-0.01 \pm 0.01$ & $0.00 \pm 0.01$ & $0.00 \pm 0.02$ & 0.00 & 0.00 & $0.87 \pm 0.42$ \\
\hline 146 & 242 & nd & nd & nd & nd & nd & nd \\
\hline 101 & 530 & $0.00 \pm 0.00$ & $0.00 \pm 0.00$ & $0.05 \pm 0.03$ & 0.01 & 0.06 & $0.53 \pm 1.71$ \\
\hline 086 & 550 & $0.00 \pm 0.05$ & $-0.02 \pm 0.06$ & $0.05 \pm 0.09$ & 0.00 & 0.05 & $0.35 \pm 0.09$ \\
\hline 119 & 486 & $-0.02 \pm 0.03$ & $0.01 \pm 0.00$ & $0.02 \pm 0.01$ & 0.10 & 0.13 & $2.11 \pm 1.70$ \\
\hline 100 & 869 & $-0.01 \pm 0.01$ & $-0.01 \pm 0.00$ & $-0.03 \pm 0.08$ & 0.01 & 0.00 & neg \\
\hline 134 & 273 & $0.00 \pm 0.00$ & $0.00 \pm 0.00$ & $-0.07 \pm 0.10$ & 0.00 & 0.00 & $0.26 \pm 0.26$ \\
\hline \multicolumn{8}{|c|}{ Group 3} \\
\hline 105 & 405 & $0.00 \pm 0.00$ & $0.00 \pm 0.00$ & $0.03 \pm 0.04$ & 0.00 & 0.03 & $0.68 \pm 0.63$ \\
\hline 098 & 2577 & -0.01 & $-0.04 \pm 0.03$ & 0.125 & 0.00 & 0.13 & 1.15 \\
\hline 112 & 1010 & $0.00 \pm 0.00$ & $0.00 \pm 0.00$ & $0.07 \pm 0.01$ & 0.00 & 0.07 & $1.42 \pm 0.54$ \\
\hline 108 & 2490 & $0.00 \pm 0.00$ & $0.00 \pm 0.00$ & $0.24 \pm 0.00$ & 0.00 & 0.20 & nd \\
\hline 078 & 2010 & $0.09 \pm 0.07$ & -0.03 & 0.07 & nd & 0.20 & $0.78 \pm 0.20$ \\
\hline
\end{tabular}
see Table 3). nd: not done; neg: negative value. Some replicates are missing for Stns 098 and 078 

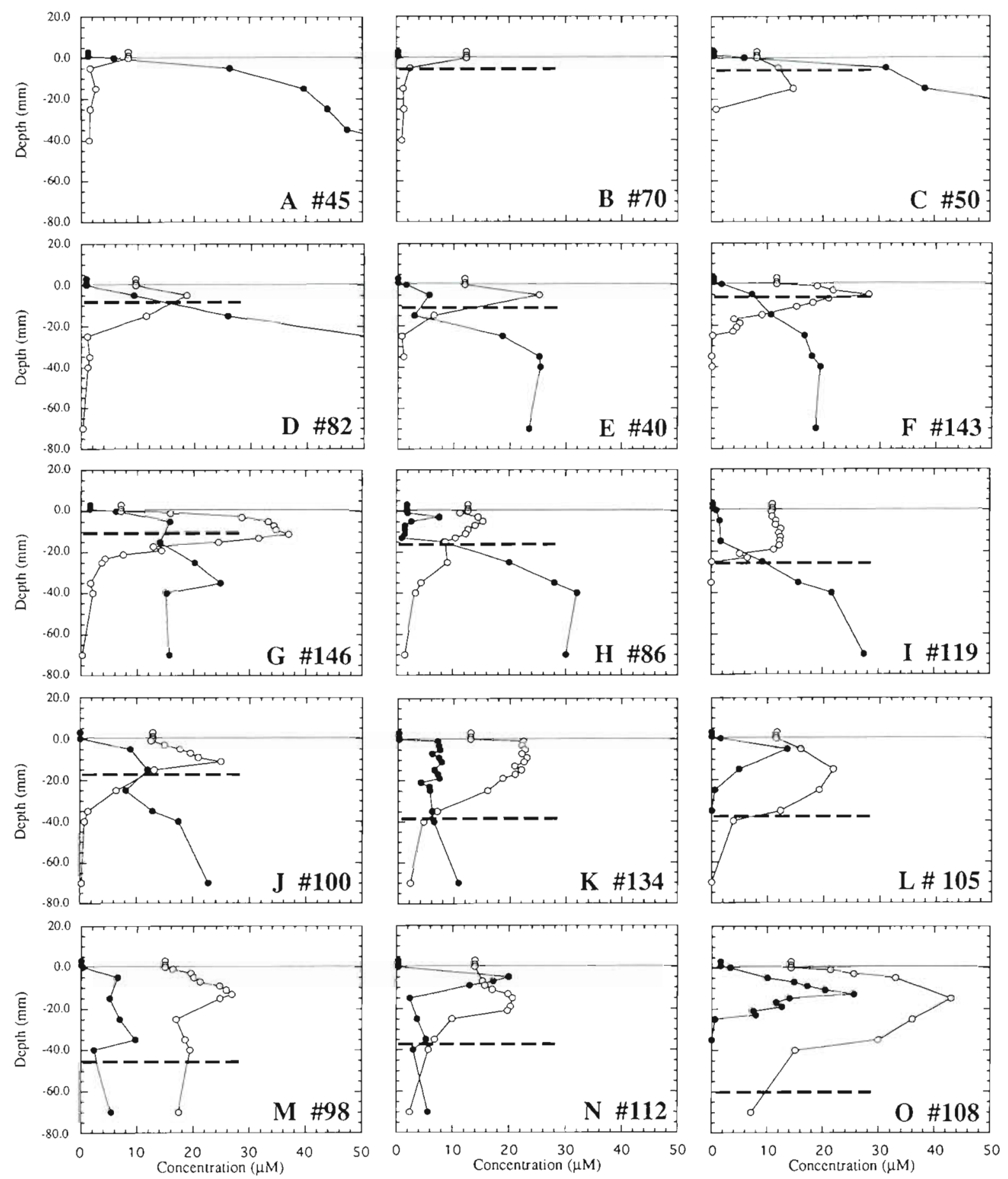

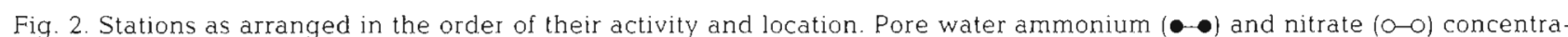
tions are plotted against sediment depth. The depth of oxygen penetration (---) is also shown (Hulth et al. 1994)

in Groups 1 and 2 had a measured $\mathrm{NO}_{3}^{-}$net influx (Table 1). All stations in Group 3 had a net efflux, both by direct measurement and by calculation. The NO3w influx was calculated from the concentration of $\mathrm{NO}_{3}{ }^{-}$in the water and the depth of $\mathrm{NO}_{3}^{-}$penetration, assuming a linear gradient from the sediment surface to the point of disappearance. This gives an underestimation of the rate, as the NO3w profile in the sediment must have had the same shape as that of the total measured $\mathrm{NO}_{3}{ }^{-}$ profile in the consumption zone, giving a steeper gradient. The efflux of NO3n was obtained by adding the NO3w influx to the calculated net efflux of $\mathrm{NO}_{3}{ }^{-}$. Similarly, the NO3n downflux was obtained by subtracting NO3w from net downflux of $\mathrm{NO}_{3}^{-}$. 
Table 2. Calculated nitrate fluxes (mmol $\left.\mathrm{m}^{-2} \mathrm{~d}^{-1}\right)$. Net fluxes were calculated from the gradients shown in Fig. 2. The approximate flux downward of nitrate from the water (NO3w) was also calculated from the gradient established between the water and the penetration depth of nitrate. The NO3n (nitrate from nitrification in the sediment) outflux was the net flux out plus the NO3w flux down. Similarly, the NO3n flux down was the net flux down minus the NO3w flux down. nd: not done

\begin{tabular}{|cccccc|}
\hline Stn & $\begin{array}{c}\text { Net flux } \\
\text { out }\end{array}$ & $\begin{array}{c}\text { Net flux } \\
\text { down }\end{array}$ & $\begin{array}{c}\text { NO3w flux } \\
\text { down }\end{array}$ & $\begin{array}{c}\text { NO3n flux } \\
\text { out }\end{array}$ & $\begin{array}{c}\text { NO3nflux } \\
\text { down }\end{array}$ \\
\hline 045 & -0.087 & 0.087 & 0.087 & 0.000 & 0.000 \\
070 & -0.134 & 0.134 & 0.134 & 0.000 & 0.000 \\
050 & 0.078 & 0.074 & 0.019 & 0.097 & 0.055 \\
082 & 0.099 & 0.081 & 0.022 & 0.121 & 0.059 \\
& & & & & \\
040 & 0.153 & 0.114 & 0.034 & 0.187 & 0.080 \\
143 & 0.252 & 0.144 & 0.025 & 0.278 & 0.119 \\
146 & 0.449 & 0.269 & 0.016 & 0.465 & 0.253 \\
101 & nd & nd & nd & nd & nd \\
086 & 0.143 & 0.047 & 0.009 & 0.152 & 0.038 \\
119 & 0.013 & 0.121 & 0.025 & 0.038 & 0.095 \\
100 & 0.062 & 0.170 & 0.021 & 0.083 & 0.149 \\
134 & 0.185 & 0.060 & 0.008 & 0.193 & 0.052 \\
& & & & & \\
105 & 0.043 & 0.097 & 0.010 & 0.052 & 0.088 \\
098 & 0.048 & 0.046 & 0.009 & 0.056 & 0.037 \\
112 & 0.105 & 0.314 & 0.010 & 0.115 & 0.304 \\
108 & 0.260 & 0.275 & 0.009 & 0.269 & 0.266 \\
078 & nd & nd & nd & nd & nd \\
\hline
\end{tabular}

The measured rates of nitrification and of denitrification (Dw and Dn) are shown in Table 3. Nitrification rates were variable, but were generally higher in Group 1 and lower in Groups 2 and 3 . Dn and Dw rates had a similar trend. PON accumulation (Table 3) varied from 0.997 (Stn 82, Group 1) to 0.045 (Stn 98, Group 3) $\mathrm{mmol} \mathrm{N} \mathrm{m}^{-2}$ $\mathrm{d}^{-1}$. Group 2 stations had intermediate accumulation rates, 0.141 to $0.475 \mathrm{mmol} \mathrm{N} \mathrm{m}^{-2} \mathrm{~d}^{-1}$.

\section{DISCUSSION}

\section{Calculated nitrate fluxes}

Most sediments had insignificant rates of nitrogen-compared to carbonmineralisation (Fig. 3). The Group 1 sediments had the largest nitrogen mineralisation rates, followed by Group 3, with Group 2 having very low values (Fig. 3A). Even the Group 1 sediments had high $\mathrm{C}: \mathrm{N}$ ratios in mineralised products (>40) and Group 2 ratios were almost 140 (Fig. 3B). As these $\mathrm{C}: \mathrm{N}$ ratios were so high in relation to the $\mathrm{C}: \mathrm{N}$ of $\sim 10$ in the sediment organic matter (Hulth et al. 1996) and the generally low $\mathrm{C}: \mathrm{N}$ of algal detritus, we suspected that there had been a failure to measure all inorganic- $N$ compounds. It seemed likely that either $\mathrm{NO}_{3}$ fluxes or denitrification had been underestimated. Net $\mathrm{NO}_{3}{ }^{-}$ fluxes, upward in the direction of the sediment surface (effluxes) and downward (possible denitrification) towards the anoxic sediment zone, were calculated from the $\mathrm{NO}_{3}{ }^{-}$gradients (Fig, 2) and are shown in Table 2. It was apparent that the calculated effluxes were much greater than the measured effluxes for Group 2 stations. This is clearly seen when the means of the measured and calculated effluxes are compared (Fig. 4A). There was little difference between the 2 rates in Groups 1 and 3. Both the measured and calculated effluxes were net, in the sense that they were the product of 2 opposite processes, i.e. the diffusion of NO3w downward from the

Table 3. Measured nitrification, denitrification and PON accumulation rates $\left(\mathrm{mmol} \mathrm{m}{ }^{-2} \mathrm{~d}^{-1}\right.$ ). Rates of PON accumulation are the daily means to give the yearly increment. PON inputs are the mean daily $N$ required to meet the consumption rates (DON efflux $+\Sigma N$ inorg. efflux + PON accumulation). nd: not done

\begin{tabular}{|cccccc|}
\hline Stn & Nitrification & \multicolumn{2}{c}{ Denitrification } & PON & $\begin{array}{c}\text { PON } \\
\text { input }\end{array}$ \\
\hline Group 1 & & & & & \\
Dn & & & & & \\
accumulation & & & & & \\
070 & 0.155 & 0.078 & 0.025 & 0.307 & 1.84 \\
050 & 0.339 & 0.065 & 0.007 & nd & \\
082 & 0.000 & 0.008 & 0.006 & 0.559 & 1.56 \\
Group 2 & 1.457 & 0.094 & 0.008 & 0.997 & 2.55 \\
040 & & & & & \\
143 & 0.053 & 0.052 & 0.028 & 0.188 & 1.02 \\
146 & nd & 0.000 & 0.001 & 0.202 & 1.08 \\
101 & nd & nd & nd & 0.285 & \\
086 & 0.053 & 0.010 & 0.009 & 0.141 & 0.74 \\
119 & 0.137 & 0.000 & 0.005 & 0.475 & 0.88 \\
100 & 0.000 & 0.104 & 0.031 & 0.318 & 2.56 \\
134 & 0.000 & 0.008 & 0.013 & 0.436 & \\
Group 3 & 0.017 & 0.000 & 0.000 & 0.176 & 0.44 \\
105 & & & & & \\
098 & 0.023 & 0.000 & 0.000 & 0.314 & 1.03 \\
112 & 0.050 & 0.000 & 0.000 & 0.045 & 1.32 \\
108 & 0.000 & 0.000 & 0.000 & 0.098 & 1.59 \\
078 & 0.048 & 0.000 & 0.000 & 0.135 & \\
& 0.064 & nd & nd & 0.203 & 1.18 \\
\hline
\end{tabular}



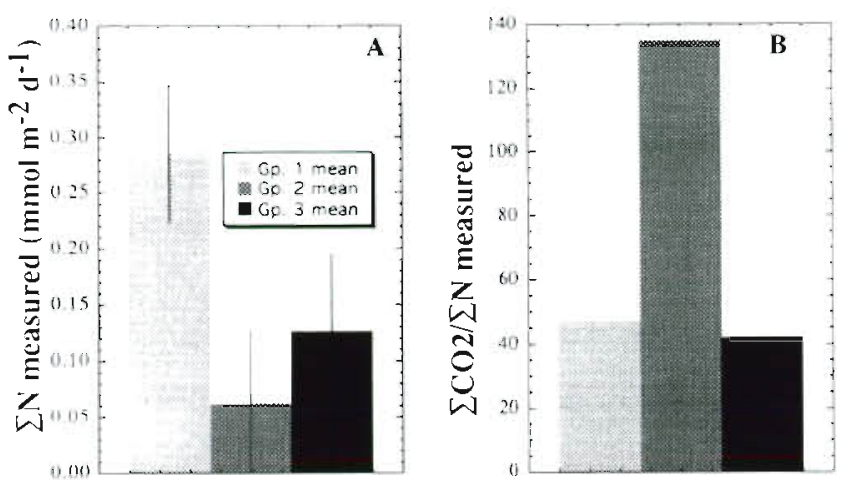

Fig. 3. Summed $N$-efflux and $C: N$ ratios. (A) $\Sigma N$ rates are the means for the 3 station groups (Table $1, \Sigma \mathrm{N}$ inorg.). (B) $\Sigma \mathrm{N}$ for each station group expressed as a ratio of measured $\Sigma \mathrm{CO}_{2}$ fluxes (Hall et al. unpubl.)

water and the diffusion of sediment NO3n upward into the water. The actual flux of NO3n upward was obtained by adding the calculated downward flux of NO3w to the calculated net efflux, as explained earlier. The calculated NO3w influx was small, particularly for Groups 2 and $3\left(<0.02 \mathrm{mmol} \mathrm{m}^{-2} \mathrm{~d}^{-1}\right.$, Fig. 5B), where $\mathrm{NO}_{3}^{-}$penetrated deep into the sediment, giving a long and flat gradient (Fig. 2). The calculated rate of denitrification of NO3n was greater than the measured (Dn) rate, except for Group 1 sediments (Fig. 4B). The measured Dn rates followed sediment activity as judged by $\mathrm{O}_{2}$ penetration (Group $1>$ Group $2>$ Group 3 ), whereas the opposite was observed for the calculated rates (Fig. 4B). The calculated rates of denitrification of NO3w were also greater than the measured (Dw) rates, but the calculated rates of denitrification followed sediment activity (Fig 5B). Another independent estimate of denitrification (nitrification - NO3n efflux) was based on the hypothesis that: nitrification = NO3n efflux + denitrification (Blackburn 1986).

However, the measured nitrification rates were variable within the groups. They were substantially lower, with the exception of Group 1, than the calculated rates (NO3n efflux + NO3n downflux, Fig. 5A). It is very probable, as we discuss later, that the above equation was incorrect in the present situation. More likely, nitrification equalled NO3n efflux + Dn + NO3n assimilation into bacteria.

New maximum $\Sigma N$ efflux rates were obtained, in which the calculated nitrification rates were added to the positive effluxes of $\mathrm{NH}_{4}{ }^{+}$and urea to give the total mineralised $N$. These new $\sum N$ values were almost certainly too large, as they were based on the assumption that no assimilation of $\mathrm{NO}_{3}{ }^{-}$had occurred. The ratios of $\Sigma \mathrm{CO}_{2}$ :new $\Sigma \mathrm{N}$ varied from $\sim 50$ to $\sim 20$ (Fig. $4 \mathrm{C}$ ): these were still very high values for the $\mathrm{C}: \mathrm{N}$ ratio in the substrate, so it must be concluded that the substrate did have a low nitrogen content.

\section{Nitrogen budget}

The measured values for nitrogen mineralisation (Table 1) were used, with the rate of PON burial and the rate of DON efflux, to calculate the rate at which PON must have reached the sediment surface (Table 3). Surprisingly, considering the wide range of water depths, the required inputs of PON showed little correlation with station grouping: the highest
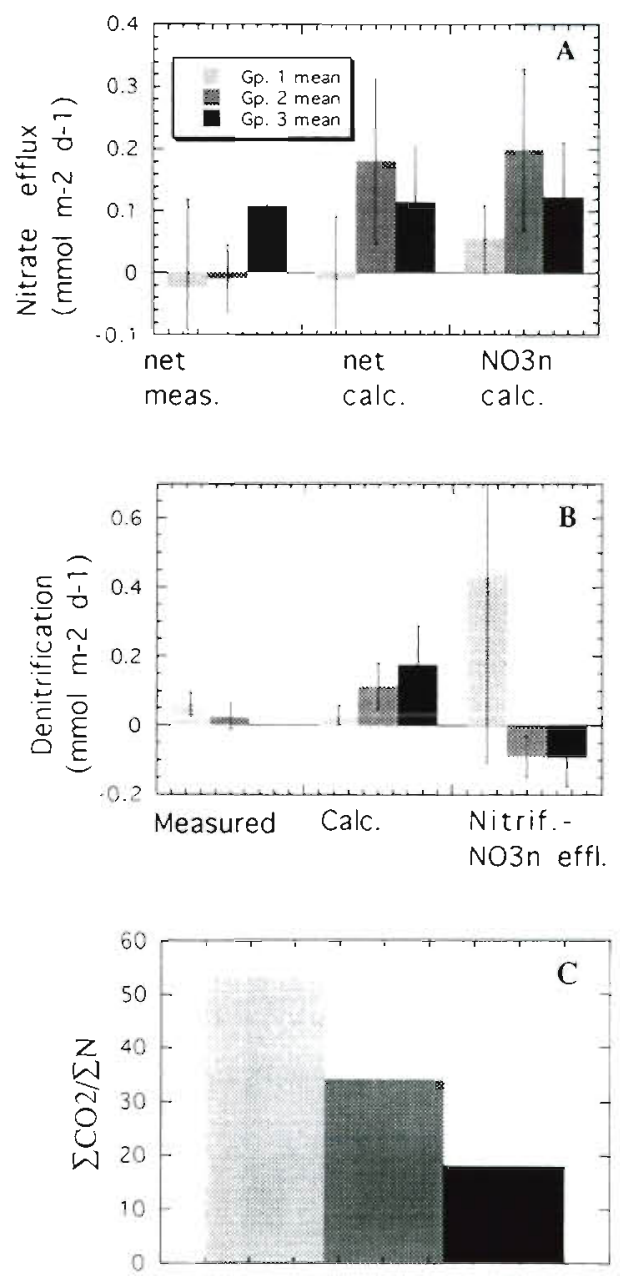

Fig. 4. Comparison of different values in the sediment for (A) nitrate efflux, (B) denitrification of nitrate from the sediment (NO3n), (C) calculation of minimum C: $N$ mineralisation ratios. Data are presented as means, with SD, of data from stations within the 3 groups. Nitrate efflux was obtained by direct measurement (net measured, Table 1), by calculation of the net efflux (Table 2) and by correction of these values for nitrate influx from the water (Table $2, \mathrm{NO} 3 \mathrm{n}$ flux out). Denitrification of NO3n was obtained by direct measurement (Table 3, Dn), by calculation (Table 2, NO3n flux down), and by subtracting NO3n efflux (Table 2 ) from the measured nitrification rate (Table 3). Dn was zero for Group 3 stations. The measured $\mathrm{SCO}_{2}$ fluxes (Hall et al. unpubl.) were divided by $\sum N$ fluxes (positive fluxes of ammonium + urea + NO3n flux down + NO3n flux out) 

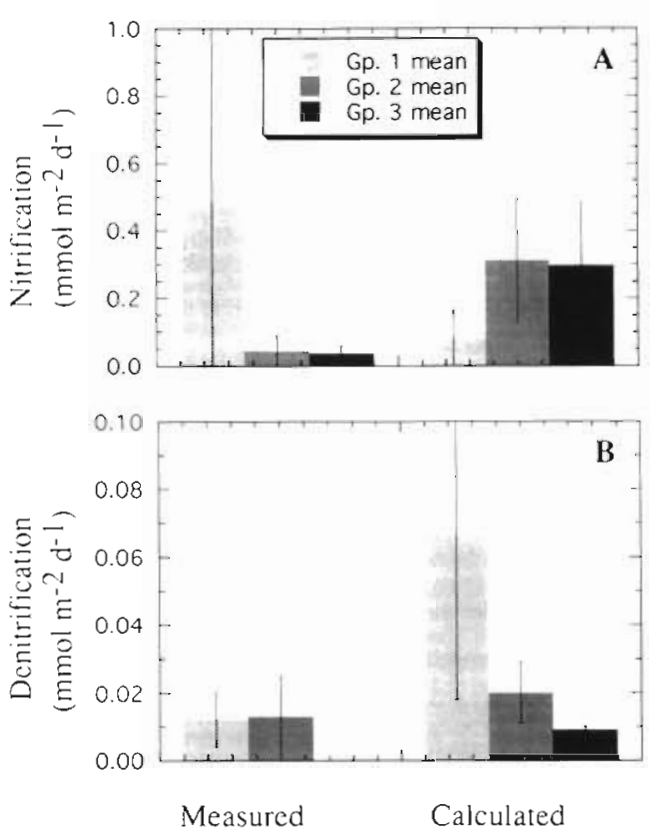

Fig. 5. Comparison of measured and calculated rates of (A) nitrification and $(B)$ denitrification of nitrate from the water (NO3w). In (A), the measured rates of nitrification (Table 3) and the calculated rates (Table 2, ¿NO3n fluxes) are plotted for each group of stations. In (B), the measured rates of denitrification of NO3w (Table 3, Dw) and the calculated rate (Table 2, NO3w influx) are plotted for each group of stations. Dw was zero for Group 3 stations

$\left(2.56 \mathrm{mmol} \mathrm{m} \mathrm{m}^{-2} \mathrm{~d}^{-1}\right)$ and lowest $\left(0.44 \mathrm{mmol} \mathrm{m}^{-2} \mathrm{~d}^{-1}\right)$ values were in Group 2. These data were incorporated into a mean $\mathrm{N}$ budget for the Svalbard region (Fig. 6). It is not representative for all seasons, but reflects the situation in July 1991. The 2 most important features of this budget were the very high efflux of DON $\left(0.93 \mathrm{mmol} \mathrm{m} \mathrm{m}^{-2} \mathrm{~d}^{-1}\right)$ compared to the low efflux of DIN $\left(0.14 \mathrm{mmol} \mathrm{m}^{-2} \mathrm{~d}^{-1}\right)$. Presumably, the high DON efflux was a temporary phenomenon associated with the sedimentation of fresh detrital material from the photic zone. If the DON which effluxed had a relatively low $\mathrm{C}: \mathrm{N}$ ratio (e.g. 6), then the sedimenting detritus would have had a $\mathrm{C}: \mathrm{N}$ ratio of 13 . If there had not been an efflux of nitrogen-rich dissolved organic material from the sediment surface, the sedimented detritus would have had a C:N ratio of 28. This was a result of the complete mineralisation of very high C:N substrate (68) and the burial of relatively low C:N (10) organic matter. Considered from another angle, if the organic substrate in the sediment had a high $\mathrm{C}: \mathrm{N}$ and the organic matter which was buried had a low $\mathrm{C}: \mathrm{N}$, then little nitrogen could escape to the overlying water. This would suggest that assimilation of DIN must be important in these sediments.

\section{Patterns of inorganic nitrogen assimilation}

Assimilation of both $\mathrm{NH}_{4}{ }^{+}$and $\mathrm{NO}_{3}{ }^{-}$are suggested by the individual station profiles (Fig. 2) and in the summary group profiles (Fig. 7). The rates of $\mathrm{NO}_{3}{ }^{-}$ assimilation (Fig. 7) were calculated as follows: The uptake of $\mathrm{NO}_{3}{ }^{-}$to the surface side of the $\mathrm{NO}_{3}{ }^{-}$peak was derived from the calculated net efflux of $\mathrm{NO}_{3}$ minus its measured net efflux rate. The uptake rate of $\mathrm{NO}_{3}{ }^{-}$on the down side of the $\mathrm{NO}_{3}{ }^{-}$peak was derived from the calculated net downflux of $\mathrm{NO}_{3}^{-}$minus the summed measured rates of denitrification ( $D n+D w)$. The contribution of $\mathrm{NO} 3 \mathrm{n}$ was much greater than that of NO3w, except for Group 1 sediments. We had used the $\mathrm{NH}_{4}{ }^{+}$profiles, in conjunction with $\mathrm{NO}_{3}{ }^{-}$and $\mathrm{O}_{2}$, to arrange the stations in order of decreasing activity (Fig. 2), but we did not want to rely too heavily on $\mathrm{NH}_{4}{ }^{+}$ profiles, as $\mathrm{NH}_{4}{ }^{+}$concentrations can increase in sample processing, especially in sediments from great depth (Berelson et al. 1990, R. Aller, P. Hall, J. Mackin \& P. A.ller unpubl.). In addition, an attempt to model the $\mathrm{NH}_{4}{ }^{+}, \mathrm{NO}_{3}{ }^{-}$and $\mathrm{O}_{2}$ profiles was only partially successful, because assimilation of $\mathrm{NH}_{4}{ }^{+}$and $\mathrm{NO}_{3}{ }^{-}$was not included (Blackburn \& Blackburn 1993b). The mean $\mathrm{NH}_{4}{ }^{+}$profiles for each group of stations, however, will be seen to fit well. with the $\mathrm{NO}_{3}$ - profiles and with the proposed zones of $\mathrm{NO}_{3}{ }^{-}$uptake (Fig 7 ).

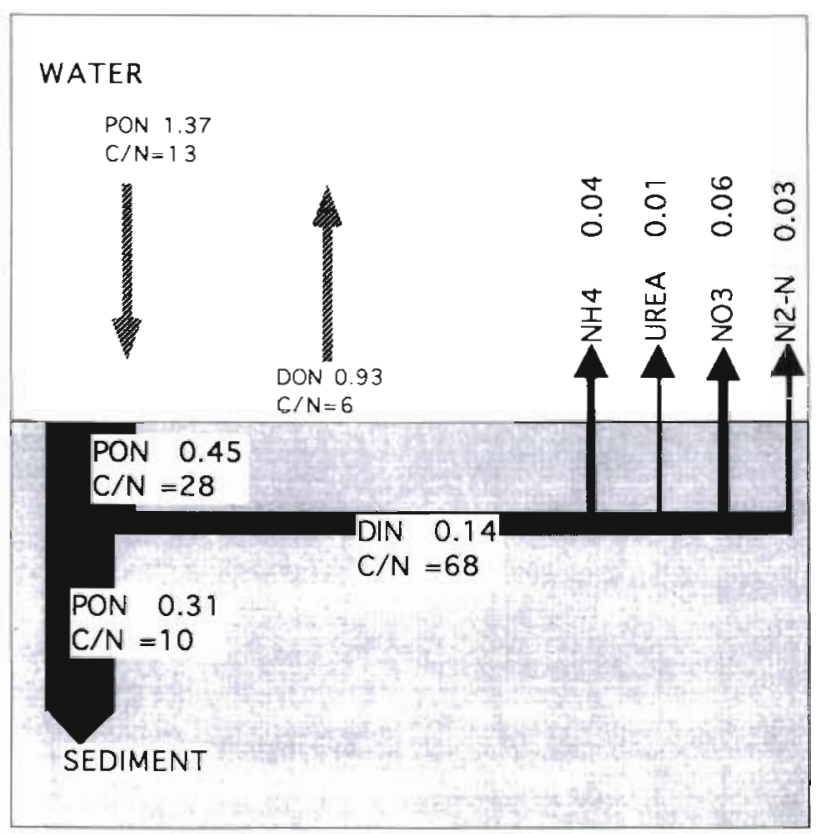

Fig. 6. Nitrogen budget for Svalbard sediments. Rates (mmol $\mathrm{m}^{-2} \mathrm{~d}^{-1}$ ) are mean values for all stations. The C: $\mathrm{N}$ ratio in the effluxing dissolved organic matter was not measured: a value of 6 was chosen. Rates of carbon input, burial and mineralisation will be reported elsewhere (Hall et al. unpubl.) 


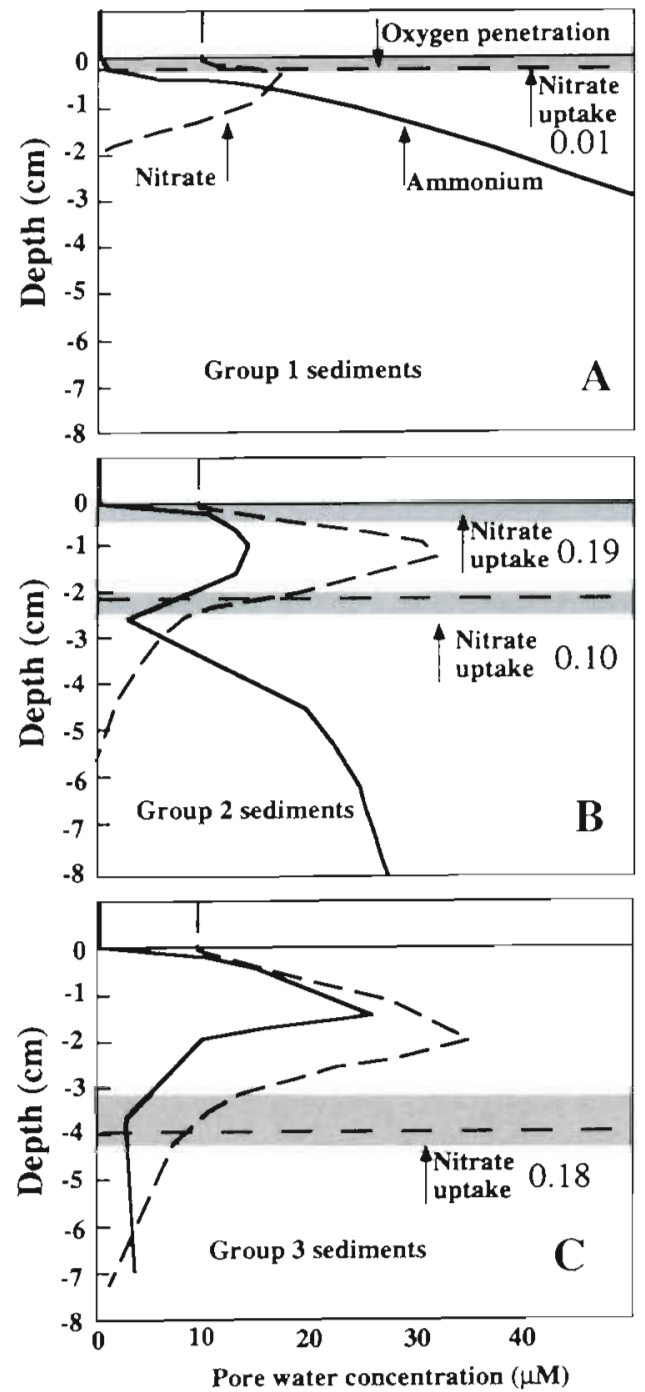

Fig. 7 Proposed zones of nitrate uptake through bacterial assimilation. Idealised $\mathrm{O}_{2}$ penetration depth and pore water concentration profiles of $\mathrm{NH}_{4}{ }^{-}$and $\mathrm{NO}_{3}{ }^{-}$are shown for the 3 groups of sediments. The probable location of $\mathrm{NO}_{3}$ assimilation is indicated by grey shading, and rates are given in mmol $\mathrm{m}^{-2} \mathrm{~d}^{-1}$ Calculation of the assimulation rates is discussed in the text

There was considerable variability among the Group 1 stations, so the summary profiles (Fig. 7A) are not representative of all stations. The limited $\mathrm{O}_{2}$ penetration and the high $\mathrm{NH}_{4}{ }^{+}$concentrations are correct, but the $\mathrm{NO}_{3}{ }^{-}$profile (Fig $7 \mathrm{~A}$ ) is only characteristic for Stns 50 and 82 (Fig. 2C, D). The Group 2 sediment summary (Fig. 7B) is quite representative of the individual sediments with respect to a deep penetration of $\mathrm{O}_{2}, \mathrm{NH}_{4}{ }^{+}$concentrations $<30 \mu \mathrm{M}$, with a shallow gradient from the deep sediment, and a characteristic concavity in the profile below the oxic zone in all except $\mathrm{Stn} 134$ (Fig. 2K). The $\mathrm{NO}_{3}{ }^{-}$profiles were more vari- able, but all except Stn 119 and Stn 134 (Fig. 2I, K) had sharp peaks at $-1.0 \mathrm{~cm}$ depth, as in Fig $7 \mathrm{~B}$. The 4 sediments in Group 3 (Fig. 2L, M, N, O) all had similar deep penetration of $\mathrm{O}_{2}$, little diffusion of $\mathrm{NH}_{4}{ }^{+}$from below, but evidence of $\mathrm{NH}_{4}{ }^{+}$production close to the surface, and broad $\mathrm{NO}_{3}{ }^{-}$peaks with deep $\mathrm{NO}_{3}{ }^{-}$penetration, similar to the representation in Fig. $7 \mathrm{C}$.

We feel that Fig 7 adequately mirrors the 3 basic patterns observed in these sediments and that they may be used to draw general conclusions regarding sediment processes. The active zone in Group 1 sediments (Fig. 7A) was so close to the surface that it was difficult to analyse the gradients, but there was some $\mathrm{NO}_{3}{ }^{-}$uptake $\left(0.01 \mathrm{mmol} \mathrm{m}^{-2} \mathrm{~d}^{-1}\right)$ close to the surface, and almost certainly $\mathrm{NH}_{4}{ }^{+}$uptake also, as $\mathrm{NH}_{4}{ }^{+}$fluxes were smaller (Table 1) than expected from the gradients (Fig. 2). In addition, there was certainly also some incorporation of $\mathrm{NO}_{3}^{-}$from the overlying water. We suggest that most $\mathrm{NH}_{4}{ }^{+}$came by ditfusion from below $0.2 \mathrm{~cm}$ depth and that some was assimilated by bacteria using relatively high $\mathrm{C}: \mathrm{N}$ substrate close to the sediment surface. It is unlikely that there was any $\mathrm{NO}_{3}{ }^{-}$ assimilation below the $\mathrm{NO}_{3}{ }^{-}$peak, as $\mathrm{NH}_{4}{ }^{+}$was in high concentration. It is probable that quite vigorous nitrification occurred, as evidenced by the high measured rates (Fig. 5A). The low measured nitrification rates for Groups 2 and 3 (Fig. 5A) were probably artefacts of the assay procedure. The $\mathrm{NH}_{4}{ }^{+}$, spared by acetylene inhibition of nitrification at some depth in the sediment, was almost certainly assimilated by bacteria before it could diffuse to the surface. It is thus consistent that the calculated rates of nitrification for these groups are higher than the measured values. This can also explain why Dn can be greater than nitrification (Table 3).

Group 2 sediments present the most interesting picture. Some $\mathrm{NH}_{4}{ }^{+}$diffused from below, but some was also produced at $-1.0 \mathrm{~cm}$. The profile indicated an uptake of $\mathrm{NH}_{4}{ }^{+}$at $-2.5 \mathrm{~cm}$, and the small and irregular efflux (Table 1) indicated further uptake close to the sediment surface. There was also $\mathrm{NO}_{3}{ }^{-}$uptake on the upper side $\left(0.19 \mathrm{mmol} \mathrm{m}^{-2} \mathrm{~d}^{-1}\right)$ and lower side $\left(0.10 \mathrm{mmol} \mathrm{m}^{-2} \mathrm{~d}^{-1}\right)$ of the $\mathrm{NO}_{3}{ }^{-}$peak, presumably because $\mathrm{NH}_{4}{ }^{+}$concentrations were too low to be inhibitory.

Group 3 sediments (Fig. 7C) showed a further progression from the Group 2 pattern. Very little $\mathrm{NH}_{4}{ }^{+}$diffused from below, and most $\mathrm{NH}_{4}{ }^{+}$was produced at $\sim 1.5 \mathrm{~cm}$. As no $\mathrm{NH}_{4}{ }^{+}$diffused into the overlying water (except at Stn 78, Table 1) it must have been assimilated on the upper side of the $\mathrm{NH}_{4}{ }^{+}$peak, as this did not seem to be a zone of active nitrification. There was also $\mathrm{NH}_{4}{ }^{+}$assimilation on the lower side of the $\mathrm{NH}_{4}{ }^{+}$ peak, as indicated by a concavity in the profile, again in a zone of low nitrification. Nitrate assimilation did not occur on the upper side of the $\mathrm{NO}_{3}^{-}$peak, presumably as there was an equal concentration of $\mathrm{NH}_{4}{ }^{+}$ 
Table 4. Sediment nitrogen fluxes

\begin{tabular}{|c|c|c|c|}
\hline Reference & Sediment site & Depth & Observation \\
\hline Anderson et al. (1986) & Gullmarsfjorden, Sweden & Shallow & $\sum \mathrm{CO}_{2} /\left(\mathrm{NO}_{3}+\mathrm{NH}_{4}{ }^{\circ}\right): 11-18$ \\
\hline Forja et al. (1994) & Bay of Cadiz, Spain & Shallow & $\sum \mathrm{CO}_{2} /\left(\mathrm{NO}_{3}+\mathrm{NH}_{4}^{+}\right): 21$ \\
\hline Nedwell \& Walker (1995) & Signy Island, Antarctica & Shallow & $\mathrm{O}_{2} / \mathrm{NH}_{4}{ }^{*}: 114-167$, influx $\mathrm{NO}_{3}^{-}$ \\
\hline Overnell et al. (1995) & Loch Linne, Scotland & Shallow & $\mathrm{O}_{2} /\left(\mathrm{NO}_{3}+\mathrm{NH}_{4}{ }^{+}\right): 17-$ inf. \\
\hline Henriksen et al. (1993) & N. Bering Sea area, USA & Shallow & $\mathrm{O}_{2} /\left(\mathrm{NO}_{3}^{-}+\mathrm{NH}_{4}^{+}\right): 17-29$ \\
\hline Enoksson (1993) & Laholm Bay, Sweden & Shallow & $\mathrm{O}_{2} /\left(\mathrm{NO}_{3}+\mathrm{NH}_{4}{ }^{+}\right): 33-42$ \\
\hline Alongi (1995) & Gulf of Papua, Papua New Guinea & Shallow & $\mathrm{O}_{2} /\left(\mathrm{NO}_{3}+\mathrm{NH}_{4}^{+}\right): 31$ \\
\hline Berelson et al. (1990) & Central equat. N. Pacific & $4500 \mathrm{~m}$ & $\mathrm{O}_{2} / \mathrm{NO}_{3}: 11-16$ \\
\hline Bender et al $\{1989\}$ & San Clemente Basin, USA & $1900 \mathrm{~m}$ & Influx $\mathrm{NO}_{3}{ }^{-}$, no efflux $\mathrm{NH}_{4}{ }^{+}$ \\
\hline Jahnke (1990) & Santa Monica Basin, USA & $900 \mathrm{~m}$ & Influx $\mathrm{NO}_{3}{ }^{-}$, no efflux $\mathrm{NH}_{4}{ }^{+}$ \\
\hline Christensen et al. (1987) & $\begin{array}{l}\text { Continental Shelf, Mexico; } \\
\text { Gulf of Maine, USA }\end{array}$ & Shelf & Influx $\mathrm{NO}_{3}{ }^{-}$, no efflux $\mathrm{NH}_{4}^{+}$ \\
\hline
\end{tabular}

However, there was probably considerable $\mathrm{NO}_{3}^{-}$uptake $\left(0.18 \mathrm{mmol} \mathrm{m}^{-2} \mathrm{~d}^{-1}\right)$ on the lower side, but this estimate was based on the difference between the calculated $\mathrm{NO}_{3}{ }^{-}$downflux and the measured total rate of denitrification. Measured denitrification was zero for this sediment group, possibly because the cores were too short $(3.8 \mathrm{~cm})$ to include the entire denitrification zone. In addition, the incubation time ( 2 to $3 \mathrm{~d}$ ) may have been insufficient to allow ${ }^{15} \mathrm{NO}_{3}{ }^{-}$to diffuse to the denitrification zone. However, in this deep zone there was probably an uptake of $\mathrm{NH}_{4}{ }^{+}$, indicating an assimilatory demand for nitrogen, so it is likely that $\mathrm{NO}_{3}{ }^{-}$ assimilation also occurred. The oxidation of $\mathrm{NH}_{4}{ }^{+}$by $\mathrm{NO}_{3}{ }^{-}$in a denitrification reaction is another and attractive explanation for the disappearance of both compounds (Bender et al. 1989).

It is difficult to explain what happened in the zone of $\mathrm{NH}_{4}{ }^{+}$production, particularly with regard to Group 2, where this zone was bordered on both sides by zones of $\mathrm{N}$ uptake. Presumably, as the sedimenting substrate had a high $\mathrm{C}$ : $\mathrm{N}$ ratio (Fig. 6), $\mathrm{NH}_{4}{ }^{+}$was produced from the degradation of biomass rather than substrate. Perhaps there was an enrichment of biomass in the $\mathrm{NH}_{4}{ }^{+}$ production zone by, e.g., meiofaunal predation of bacteria in the uptake zones. Alternatively, bacteria from the adjacent uptake zones may have migrated into the $\mathrm{NH}_{4}{ }^{+}$production zone, where they were mineralised.

These sediments had unusual characteristics: very high efflux of DON (68\% of the sedimented PON) and very high $\mathrm{C}: \mathrm{N}$ in mineralised products associated with high rates of $\mathrm{NH}_{4}{ }^{+}$and $\mathrm{NO}_{3}{ }^{-}$immobilisation into biomass and detritus ( $\mathrm{C}: \mathrm{N} 10$ ). There are, however, some references to similar events in other marine sediments.

\section{Evidence in the literature for high $\mathrm{C}: \mathrm{N}$ substrate}

There are few references in the literature to high rates of DON efflux from sediments, but hydrolysis of organic detritus at the surface of the sediment can lead to a large diffusional loss of DON to the overlying water. Models have predicted this to be $-50 \%$ of sedimenting PON (Blackburn \& Blackburn 1993a, Blackburn 1995); large (>3 mmol $\mathrm{m}^{-2} \mathrm{~d}^{-1}$ ) effluxes were measured from microcosms to which algal material had been added (Hansen \& Blackburn 1992) and smaller fluxes $\left(0.43 \mathrm{mmol} \mathrm{m} \mathrm{m}^{-2} \mathrm{~d}^{-1}\right)$ were measured from southeastern Kattegat sediments (Enoksson 1993). Large benthic DON effluxes ( 0.4 to $3.2 \mathrm{mmol} \mathrm{N} \mathrm{m}^{-2} \mathrm{~d}^{-1}$ ) were measured on the eastern Canadian contintental shelf (Landén et al. 1996) and in the Skagerrak (Hall et al. 1996).

There are some data suggesting high $C: N$ ratios of mineralisation, but often $\mathrm{O}_{2}$ uptake must be taken as a proxy for $\mathrm{SCO}_{2}$ production (Table 4). Often, there is also a lack of information on the efflux of $\mathrm{N}_{2}$ (denitrification) and of urea. Because of this deficiency, the estimated ratios may be too large. Urea effluxes can be quite high in Arctic sediments (Lomstein et al. 1989); and under certain circumstances, coupled nitrificationdenitrification is predicted to be high (Blackburn 1996). As the relevance of the citations in Table 4 to the present situation is doubtful, they will not be discussed in detail, but the deep-sea sediments tend to be most similar to ours. For example, $\mathrm{NO}_{3}{ }^{-}$flux could be out or into the sediment, and there was no $\mathrm{NH}_{4}{ }^{+}$efflux. The picture is consistent with a nitrogen deficit in the sediment.

The present data indicate preferential nitrogen hydrolysis and mineralization of organic material in the water and the sediment. Microcosm studies have shown preferential $\mathrm{N}$ mineralisation to occur in sediments (Kristensen \& Blackburn 1987). This process also occurs in north Bering Sea sediments during the summer, residual high $C: N$ detritus being degraded in the winter (Blackburn 1987). The present data also suggest the bacterial assimilation (immobilisation) of inorganic nitrogen. This has been shown for sediments in the 
Limfjorden, Denmark, by a ${ }^{15} \mathrm{NH}_{4}{ }^{+}$dilution method (Blackburn 1980) and in Bering Shelf sediments by mass balance (Lomstein et al. 1989).

In conclusion, DON may be lost from the sediment when hydrolysis of particulates occurs at the surface of the sediment. This loss of low C:N soluble organic material results in a residue of high $\mathrm{C}: \mathrm{N}$. Nitrogen is retained by the sediment, resulting in a low efflux of inorganic nitrogen and in the creation of a low $\mathrm{C}: \mathrm{N}$ organic detritus, some of which is buried. Nitrogen retention entails the assimilation of both $\mathrm{NH}_{4}{ }^{+}$and $\mathrm{NO}_{3}{ }^{-}$, the latter often from the overlying water.

Acknowledgements. We thank the chief scientists G. Hempel and E. Rachor for help and support, as well as the captain and his skillful crew on the RV 'Polarstern' (which was made available by the Alfred Wegener Institut für Polar und Meeresforschung) for assistance during the cruise. We thank the Danish Science Research Council (THB) and the Swedish Natural Science Research Council (POJH) for financial support. The project (Study of European Arctic Shelves, SEAS) was organised by the European Science Foundation (ESF).

\section{LITERATURE CITED}

Alongi DM (1995) Decomposition and recycling of organic matter in muds of the Gulf of Papua, northern Coral Sea Cont Shelf Res 15:1319-1337

Anderson LG, Hall POJ, Iverfeldt $\AA$, Rutgers van der Loeff MM, Sundby B, Westerlund SFG (1986) Benthic respiration measured by total carbonate production. Limnol Oceanogr 31:319-329

Bender $M$, Jahnke $R$, Weiss $R$, Martin $W$, Heggie DT, Orchardo J, Sowers T (1989) Organic carbon oxidation and benthic nitrogen and silica dynamics in San Clemente Basin, a continental borderland site. Geochim Cosmochim Acta 53:685-697

Berelson WM, Hammond DE, O'Neill D, Xu XM, Chin C, Zukin J (1990) Benthic fluxes and pore water studies from sediments of the central equatorial north Pacific: nutrient diagenesis. Geochim Cosmochim Acta 54:3001-3012

Berner RA (1980) Early diagenesis: a theoretical approach. Princeton University Press, Princeton

Blackburn TH (1980) Seasonal variations in the rate of organic- $\mathrm{N}$ mineralization in anoxic marine sediments. In: Biogéochimie de la Matière Organique à L'Interface EauSédiment Marin. Edition du CNRS, Paris, p 173-183

Blackburn TH (1986) Nitrogen cycle in marine sediments. Ophelia 26:65-76

Blackburn TH (1987) Microbial food webs in sediments. In: Sleigh MA (ed) Microbes in the sea. Ellis Horwood, Chichester, p 39-58

Blackburn TH (1995) The role and regulation of microbes in sediment nitrogen cycle. In: Joint I (ed) Molecular ecology of aquatic microbes. Springer-Verlag, Berlin, p 55-71

Blackburn TH (1996) Nitrogen gas flux from sediments: insights from simulation modelling. Aquat Microb Ecol 10 209-211

Blackburn TH, Blackburn ND (1993a) Rates of microbial processes in sediments. Phil Trans R Soc Lond A 344:49-58

Blackburn TH, Blackburn ND (1993b) A reaction diffusion modeI of C-N-S-O species in some arctuc sediments. FEMS
Microbiol Ecol 102:197-205

Blackburn TH, Henriksen K (1983) Nitrogen cycling in different types of sediments from Danish waters. Limnol Oceanogr 28:477-493

Bower CE, Holm-Hansen T (1980) A salicylate-hypochlorite method for determining ammonia in seawater. Can J Fish Aquat Sci 37:794-798

Christensen JP, Murray JW, Devol AH, Codispoti LA (1987) Denitrification in continental shelf sediments has major impact on the oceanic nitrogen budget. Global Biogeochem Cycles 1:97-116

Enoksson V (1993) Nutrient recycling by coastal sediments: effects of added algal material. Mar Ecol Prog Ser 92:245-254

Forja JM, Blasco J, Gómez-Parra A (1994) Spatial and seasonal variation of in situ benthic fluxes in the Bay of Cadiz (south-west Spain). Estuar Coast Shelf Sci 39:127-141

Hall POJ, Hulth S, Hulthe G, Landén A, Tengberg A (1996) Benthic nutrient fluxes on a basin-wide scale in the Skagerrak (north eastern North Sea). J Sea Res 35:123-137

Hansen LS, Blackburn TH (1992) Effect of algal bloom deposition on sediment respiration and fluxes. Mar Biol 112: $147-152$

Henriksen K, Blackburn TH, Lomstein BA, McRoy CP (1993) Rates of nitrification, distribution of nitrifying bacteria and inorganic $N$ fluxes in northern Bering-Chukchi shelf sediments. Cont Shelf Res 13:629-651

Hulth S. Blackburn TH, Hall POJ (1994) Arctic sediments (Svalbard): consumption and microdistribution of oxygen. Mar Chem 46:239-316

Hulth S. Hall POJ, Blackburn TH, Landén A (1996) Arctic sediments (Svalbard): pore water and solid phase distribution of C, N, P, and Si. Polar Biol 16:447-462

Jahnke RA (1990) Early diagenesis and recycling of biogenic debris at the seafloor, Santa Monica Basin, California. J Mar Res 48:413-436

Kemp WM, Sampou P, Caffrey J, Mayer M, Henrikson K, Boynton WR (1990) Ammonium recycling versus denitrification in Chesapeake Bay sediments. Limnol Oceanogr 35: 1545-1563

Kristensen E, Blackburn TH (1987) The fate of organic carbon and nitrogen in experimental marine sediment systems: influence of bioturbation and anoxia. J Mar Res 47 $231-257$

Landén A, Tengberg A, Hall POJ, Sundby B, Zhong S, Silverberg $N$, Grant J, Hatcher A (1996) Benthic organic and inorganic nitrogen fluxes on the eastern Canadian continental margin. EOS 76:162

Li YH, Gregory S (1973) Diffusion of ions in sea water and in deep-sea sediments. Geochim Cosmochim Acta 38: $703-714$

Lomstein BA, Blackburn TH, Henriksen K (1989) Aspects of nitrogen and carbon cycling in the northern Bering Shelf sediment. I. The significance of urea turnover in the mineralization of $\mathrm{NH}_{4}{ }^{+}$Mar Ecol Prog Ser 57:237-247

Nedwell DB, Walker TR (1995) Sediment-water fluxes of nutrients in an Antarctic coastal environment: influence of bioturbation. Polar Biol 15:57-64

Nielsen LP (1992) Denitrification in sediment determined from nitrogen isotope pairing. FEMS Microbiol Ecol 86: $357-362$

Overnell J, Edwards A, Grantham BE, Harvey SM, Jones KJ, Leftley JW, Smallman DJ (1995) Sediment-water column coupling and the fate of the spring phytoplankton bloom in Loch Linnhe, a Scottish fjordic sea-loch. Sediment processes and sediment-water fluxes. Estuar Coast Shelf Sci 41:1-19 
Price NM, Harrison PJ (1987) Comparison of methods for the analysis of dissolved urea in seawater. Mar Biol 94:307-317

Sloth NP, Nielsen LP, Blackburn TH (1992) Measurement of nitrification in sediment cores using acetylene inhibition. Limnol Oceanogr 37:1108-1112

Suess E (1980) Particulate organic carbon flux in the oceans - surface productivity and oxygen utilization. Nature 288:260-263

Walsh JJ, McRoy CP, Coachman LK, Goering JJ, Nihoul JJ Whitledge TE, Blackburn TH, Parker PL, Wirick CD, Shuert PG, Grebmeyer JM. Springer AM, Tripp RD

This article was submitted to the editor
Hansell DA, Djenidi S, Deleersnuder E, Henriksen K, Lund BA, Andersen P, Müller-Karger FE, Dean K (1989) Carbon and nitrogen cycling within the Bering/Chukchi Seas: source regions for organic matter effecting AOU demands of the Arctic Ocean. Prog Oceanogr 22:277-359 Walsh TW (1989) Total dissolved nitrogen in seawater: a new high-temperature combustion method and a comparison with photo-oxidation. Mar Chem 26:295-311

Wood ED, Armstrong FAJ, Richards FA (1967) Determination of nitrate in sea water by cadmium-copper reduction to nitrite. J Mar Biol Ass UK 47:23-31

Manuscript first received: March 18, 1996

Revised version accepted: July 8, 1996 